\title{
ベンザインの効率的発生法の開発
}

高木晃 ${ }^{\dagger}$

\section{Development of Efficient Methods for Benzyne Generation}

\author{
Akira Takagi ${ }^{\dagger}$ \\ Graduate School of Pharmaceutical Sciences, Osaka University; 1-6 Yamadaoka, Suita, Osaka 565-0871, Japan.
}

(Received June 30, 2017)

\begin{abstract}
2-[(Neopentyl glycolato) boryl] phenyl triflates, readily synthesized from 2-iodophenol derivatives via halogenmagnesium exchange or Miyaura borylation, were developed as new benzyne precursors. Benzynes were generated under fluoride-ion-mediated conditions and reacted immediately with various arynophiles. Herein, we describe the generation of benzynes having reactive functional groups, such as methoxycarbonyl, acetyl, bromo, and amino groups, as well as their $[4+2],(3+2)$, and $[2+2]$ cycloaddition reactions which produce corresponding benzo-fused compounds.
\end{abstract}

Key words — - benzyne; aryne; boryl group; cycloaddition; benzo fused ring

\section{1. はじめに}

ベンザイン 1 は，ベンゼン環内に三重結合を 1 つ 有する高反応性中間体で，様々な多置換ベンゼン誘 導体の合成に汎用されている. ${ }^{1-5)}$ また，その発生 法に関する研究報告も数多く, 多様な前駆体から様 々な条件で 1 を発生させることが可能である (Scheme 1). ${ }^{6-9)}$ その中でも，小林らの開発したオ ルト（トリメチルシリル）フェニルトリフラート9 を前駆体に用いる手法は，ケイ素の持つフッ素への 親和性やトリフラートの高い脱離能を活かし，極め て温和な，フッ素アニオンを用いる反応条件でのべ ンザイン発生が可能である。そのため 9 は，遷移金 属触媒反応等, 従来のベンザイン発生法では適用困 難であった反応に利用されるようになり，ベンザイ ンの化学に大きな躍進をもたらした. ${ }^{10-12)}$ 現在では 9 を基に更なる応用例も開発され，幅広い分野での

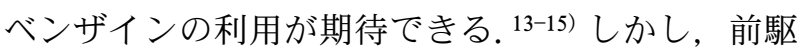
体 9 の合成には反応性の高いアルキルリチウムを用 いる必要があり, 官能基を有するベンザインを発生 させることは困難であった. ${ }^{16-18)}$ 本総説では，筆者

大阪大学大学院薬学研究科（广565-0871 大阪府吹田市 山田丘 1-6)

現所属：`神戸薬科大学（干 658-8558 神戸市東灘区本 山北町 4-19-1)

e-mail: takagi@kobepharma-u.ac.jp

本総説は, 平成 28 年度日本薬学会近畿支部奨励賞（化 学系薬学) の受賞を記念して記述したものである.
が開発した官能基共存性の高いベンザインの効率的 発生法について紹介する. ${ }^{19)}$

2. 2-ピナコラートボリルフェニルトリフラート からのベンザイン発生

まず，ベンザインの代表的な反応について概説 し，その際の反応位置の制御が難しいことを述べ る. 先述のようにベンザインは非常に反応性が高 $<$, 環化付加反応 - 求核付加反応 - 多成分連結反応 など数多くの反応に利用される。しかし，非対称に 置換されたベンザインを用いた反応では，反応生成 物が二種類の位置異性体混合物となることがしばし ばある。ベンザインの 3 位にアルコキシ基やハロゲ ンなど，電気陰性度の高い原子を有する官能基が置 換した場合には，電子的な効果と立体的な効果に よって反応位置が制御されるが, ${ }^{20-22)}$ その他の置換 基では多くの例において，十分な位置選択性が得ら れないままであった，その課題を解決すべく，筆者 は最近，ベンザイン 3 位の置換基を活用するベンザ イン反応の位置制御法の開発研究を行っていた。こ れまでに，シリル基，ボリル基が置換したベンザイ ン 1 の発生に成功し，それらが種々の基質と DielsAlder 反応, ${ }^{23-26)}(3+2)$ 付加環化反応, ${ }^{26,27)}$ 及び求 核付加反応 ${ }^{28-30)}$ を起こし，位置選択的に生成物が生 じることを見い出した．なかでもボリルベンザイン はこれまでに前例がなく，ボリル基の電子的な効果 により非常に高い選択性を示すことが明らかになつ 


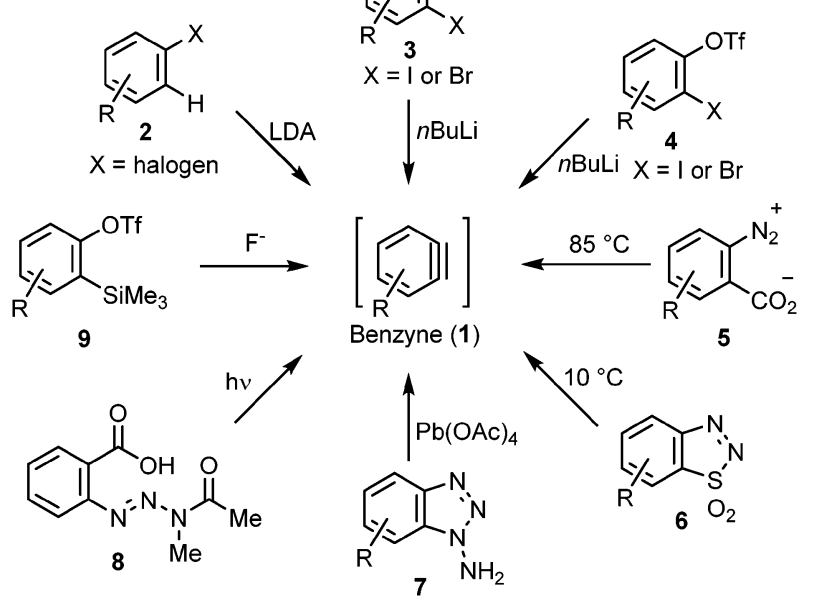

Scheme 1. Preparation of Benzynes

た（Scheme 2).さらに，ボリルベンザインとの反 応の生成物（13, 16, 20）のボリル基を種々の置換 基へ変換し，多様な多置換芳香族化合物を構築する 有用な方法であることを示した。その研究の過程で 筆者は，より温和な条件でのボリルベンザインの発 生を目的として，ボリル基を有するシリルトリフ ラート型前駆体 22 にフッ素アニオンを反応させて ボリルベンザイン 12a の発生を試みた（Scheme 3). ${ }^{24)}$ しかし， 12a の発生を示唆する環化生成物 13a の収率は低く, シリルベンザイン 23 由来の環 化生成物 $\mathbf{2 4}$ が主に得られた。これは，当初予想し た，フッ素アニオンがケイ素へ攻撃するよりもホウ 素へ攻撃する方が優先的に起こつたことを示唆して おり，2-ピナコラートボリルフェニルトリフラート がベンザイン前駆体として利用できることを示した 初めての例である。この予想外の発見を契機に，筆 者はベンザイン前駆体として 2-ボリルフェニルト リフラートを積極的に利用する研究を開始した。一 方で上記の論文発表の後に，2-ボリルフェニルトリ フラートを前駆体とするベンザイン発生法が 2 件報

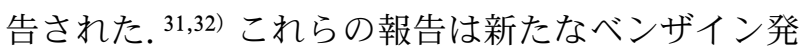
生法として有用な手法であるが，適用可能な官能基 や反応にはいまだ制限があった。そこで筆者は Scheme 3 の実験結果を基に，2-ボリルフェニルト リフラートにフッ素アニオンを作用させる温和な反 応条件を利用すれば，多様な官能基を有するべンザ インが発生できると考えた。また，比較的温和な反 応条件下に, ベンゼン環へホウ素官能基を導入する
方法がいくつか開発されているので，官能基（Fg） を有するフェノール誘導体を原料として多様な前駆 体を合成できると予想した (Scheme 4)。したがっ て，前駆体合成とベンザイン発生の両反応を温和な 条件下に行うことで，より幅広い官能基を有するべ ンザインの発生が達成できる。

\section{3. 含ホウ素前駆体からのベンザイン発生}

まず先の結果の再現性を確認するため, 置換基を 持たない 2-(ピナコラートボリル) フェニルトリフ ラート 25a を前駆体として, Scheme 3 と同様の条 件でベンザイン発生を試みた（Table 1, Entry 1). すなわち，アセトニトリル中，25a と 2,5-ジメチル フラン 11b の混合物に，フッ化セシウムを加え， $60^{\circ} \mathrm{C}$ に加熱し 24 時間擋挥した。 しかし，ベンザイ ンはほとんど発生せず，ほぼ定量的に原料を回収し た。そこで， microwave 反応装置を用い $120^{\circ} \mathrm{C}$ に加 熱したところ，収率 $56 \%$ で環化体 26 が得られた (Entry 2). 次に，ホウ素上の置換基を種々検討し た結果，ネオペンチルグリコラートボリル基 [B (neop) ］を有する前駆体 $\mathbf{2 5 b}$ を用い $120^{\circ} \mathrm{C}$ で反応 を行つたとき，ベンザイン 1 が最も効率的に発生し，

26 が収率 $85 \%$ で生成した（Entry 4)。一方，その 他の木ウ素上置換基を有する前駆体 $\mathbf{2 5} \mathbf{c}-\mathbf{2 5 i}$ を用い たときは低収率であったため（Entries 5-11），以降 の検討ではすべて B (neop) 基を有する前駆体を用 いた.

次に，官能基を有するベンザインの発生を可能と するべく，メトキシカルボニル基を有する含ホウ素 ベンザイン前駆体 27a を用いて, 詳細な条件検討を 行った（Table 2)。すなわち， 11b をベンザイン 28a の捕捉剤として用い，溶媒やフッ素アニオン 源, 反応温度, 反応時間を種々変更して付加環化生 成物 29a の収率を比較した。 その結果，フッ素アニ オン源としてフッ化セシウム，溶媒にアセトニトリ ルを用い， microwave 反応装置を用い $120^{\circ} \mathrm{C}$ で 1-2 時間反応を行うことで，環化体 29a が高収率で得ら

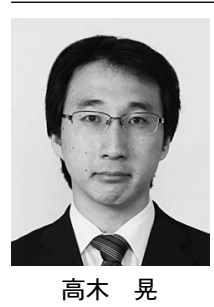

神戸薬科大学薬化学研究室 特任助教. 2008 年静岡県立大学薬学部製薬学科卒 業. 2013 年静岡県立大学大学院薬学研 究科博士後期課程修了 博士 (薬学). 2013 年マックスプランク研究所 博士 研究員, 2014 年大阪大学大学院薬学研 究科 特任助教を経て 2016 年 10 月より 現職. 

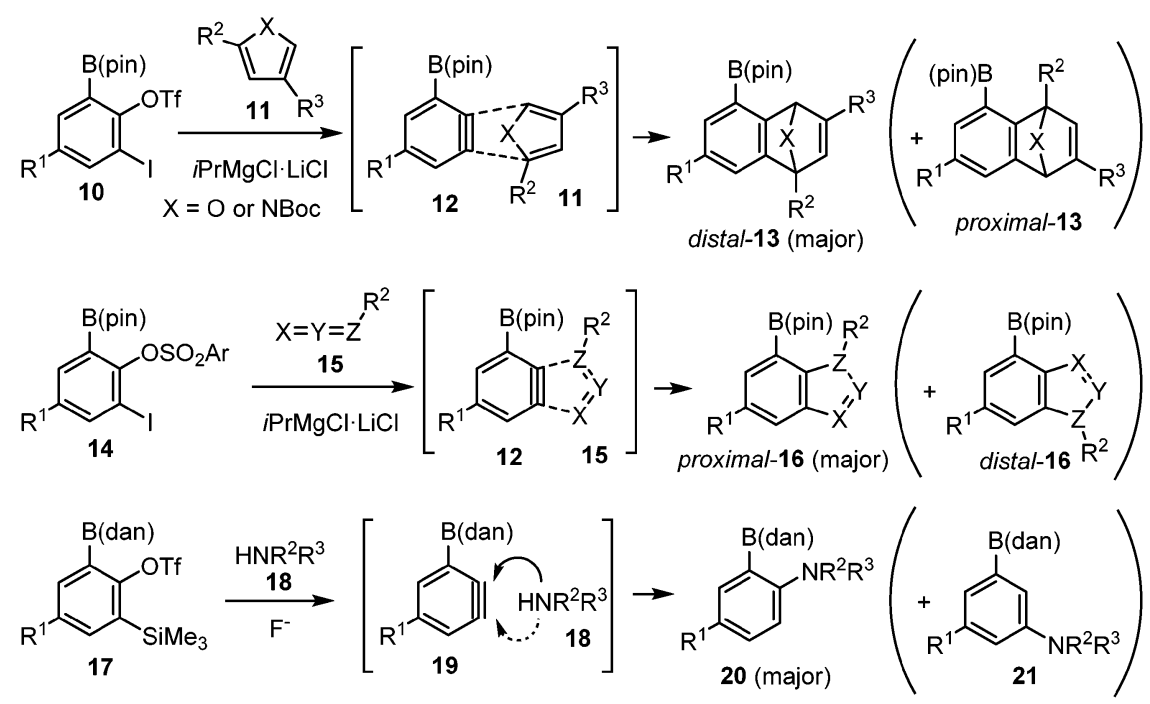

Scheme 2. Regioselective Reactions of 3-Borylbenzynes with Various Arynophiles

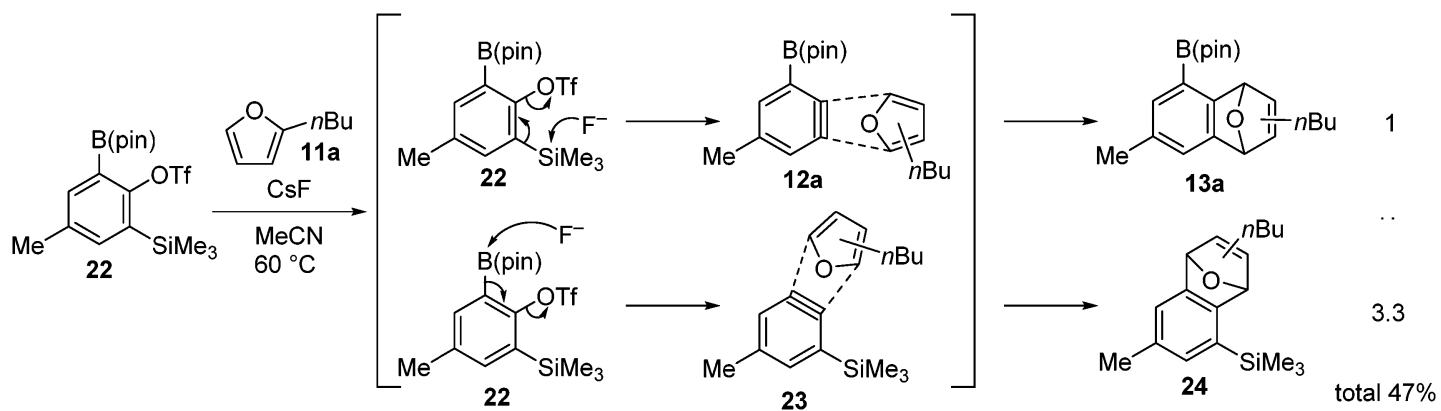

Scheme 3. Generation of 3-Silylbenzyne $\mathbf{2 3}$ by the Attack of a Fluoride Ion to the Boryl Group of 22

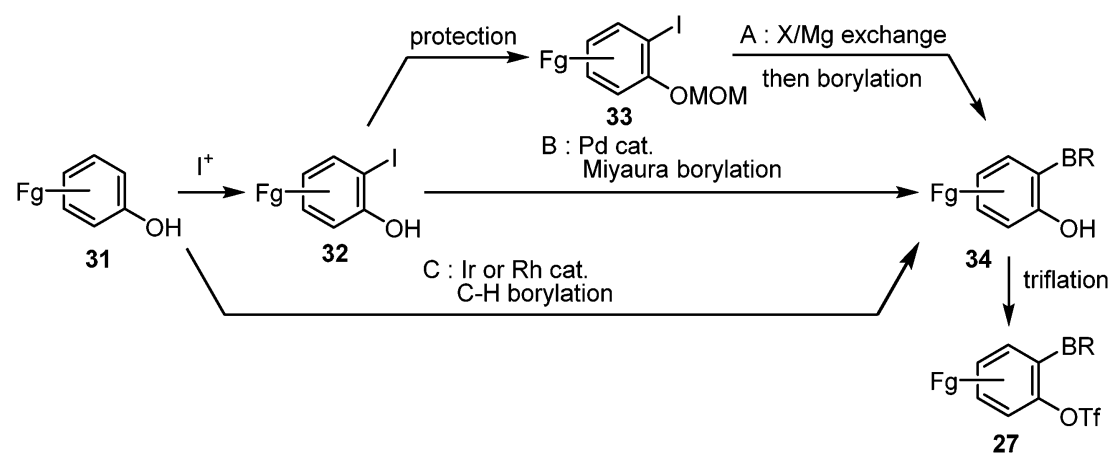

Scheme 4. Synthetic Route to Benzyne Precursors 27

れた（Entries 6 and 7)。本反応では，反応開始後 15 分後には $27 \mathbf{a}$ が完全に消費されていたが，その 時点では 29a の収率が低く (Entry 4)，その後，反 応時間を長くすることで徐々に収率が上昇したこと から (Entries 5-7)，ボレートの形成は速やかに起 こっていると考えられる，また，本反応の重要な副 生成物として, 脱ホウ素化が進行した 30 がほとん
どのケースで観察された．特に，30 は反応系中に 水が混入すると多く生成するため, フッ化セシウム を使用前に減圧下で加熱乾燥することが重要である.

4. ベンザインの新規発生法の開発を目的とした 前駆体候補化合物の合成

前述の結果より，2-ボリルフェニルトリフラート とフッ素アニオンの組み合わせが，新たな温和な反 
Table 1. Substituent Effect on Boryl Groups under Fluoride Ion Conditions ${ }^{\text {a }}$

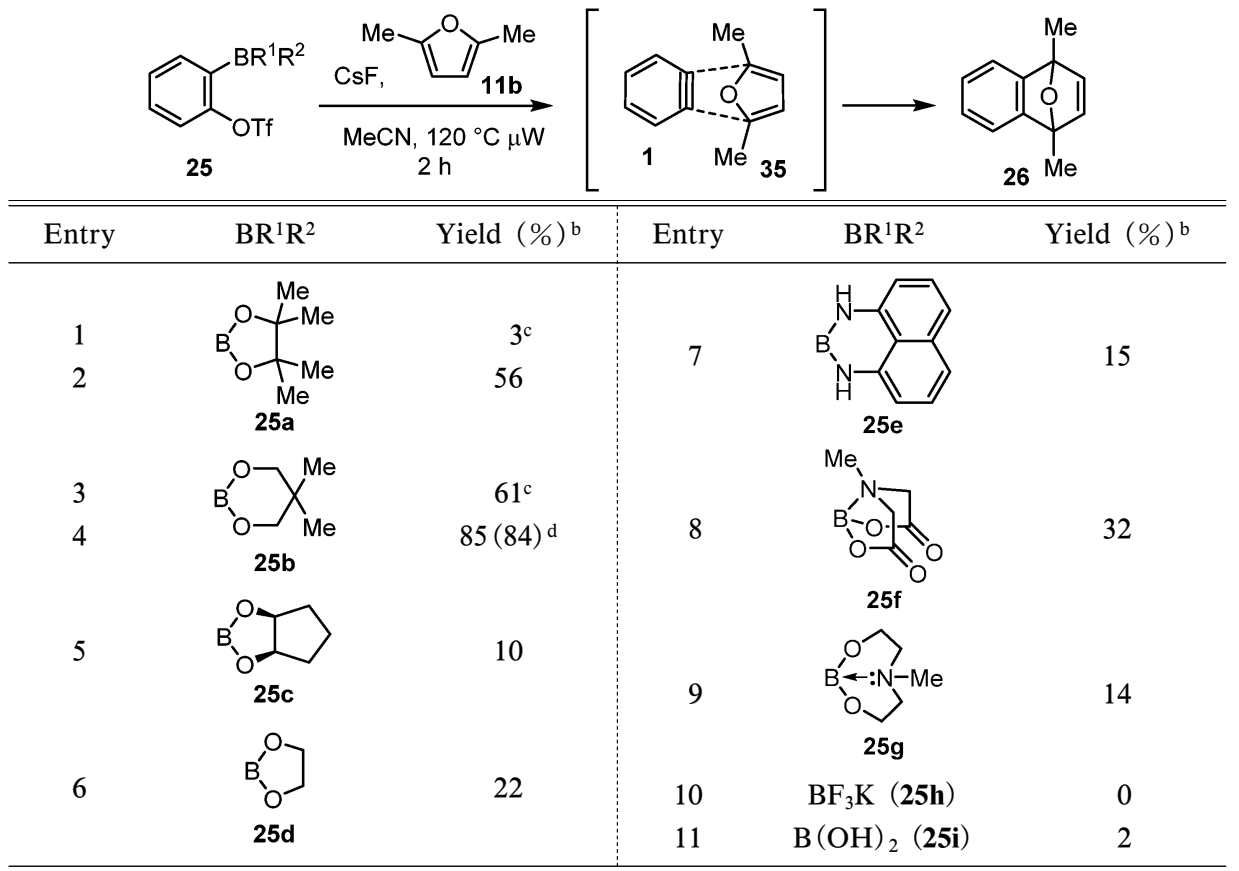

${ }^{a}$ Reaction conditions: 25 (1.0 equiv), 11b (10 equiv), $\mathrm{CsF}$ (2.0 equiv) in $\mathrm{MeCN}(0.10 \mathrm{M})$ at $120^{\circ} \mathrm{C}$ using microwave for $2 \mathrm{~h}$ unless otherwise noted. ${ }^{\mathrm{b}}$ The yield was determined via the analysis of $1 \mathrm{H}$ NMR spectra of crude products using 1,4-dimethoxybenzene as an internal standard. ${ }^{\mathrm{c}}$ The reaction was performed at $60^{\circ} \mathrm{C}$ for $24 \mathrm{~h}$ using an oil bath. ${ }^{\mathrm{d}}$ Isolated yield of $\mathbf{2 6}$ is shown in parentheses.

Table 2. Optimization of Reaction Conditions to Generation of Functionalized Benzyne ${ }^{\mathrm{a}}$

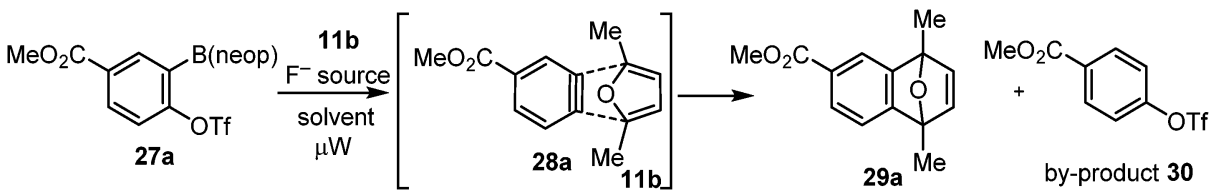

\begin{tabular}{ccccccc}
\hline \hline Entry & Solvent & $\mathrm{F}^{-}$source & Temp $\left({ }^{\circ} \mathrm{C}\right)$ & Time $(\mathrm{h})$ & Yield $(\%)^{\mathrm{b}}$ & Yield $(\%)$ of 30 \\
\hline 1 & $\mathrm{THF}$ & $\mathrm{KF}, 18-\mathrm{c}-6^{\mathrm{c}}$ & 120 & 2 & 32 & 0 \\
2 & $\mathrm{THF}$ & $\mathrm{Bu}_{4} \mathrm{NF}$ & 120 & 2 & 32 & 5 \\
3 & $\mathrm{THF}$ & $\mathrm{CsF}$ & 120 & 2 & 19 & 16 \\
4 & $\mathrm{MeCN}$ & $\mathrm{CsF}$ & 120 & 0.25 & 45 & 13 \\
5 & $\mathrm{MeCN}$ & $\mathrm{CsF}$ & 120 & 0.5 & 68 & 24 \\
6 & $\mathrm{MeCN}$ & $\mathrm{CsF}$ & 120 & 1 & $79(67)^{\mathrm{d}}$ & 5 \\
7 & $\mathrm{MeCN}$ & $\mathrm{CsF}$ & 120 & 2 & $76(67)^{\mathrm{d}}$ & - \\
8 & $\mathrm{MeCN}$ & $\mathrm{CsF}$ & $60^{\mathrm{e}}$ & 24 & 50 & - \\
\hline
\end{tabular}

a Reaction conditions: $27 \mathrm{a}$ ( 1.0 equiv), $\mathbf{1 1 b}$ (10 equiv), $\mathrm{F}^{-}$source $\left(2.0\right.$ equiv) in solvent $(0.10 \mathrm{M})$ using microwave. ${ }^{\mathrm{b}}$ The yield of 29a was determined via the analysis of $1 \mathrm{H}$ NMR spectra of crude products using 1,1,2,2-tetrachloroethane as an internal standard. c 18-c-6: 18 -crown-6. ${ }^{\mathrm{d}}$ Isolated yield of $\mathbf{3 0}$ is shown in parenthesis. ${ }^{\mathrm{e}}$ Oil bath heating.

応条件でのベンザイン発生法となる可能性が示唆さ れた。そこでまず，フェノール誘導体 31 及び 32 を 原料として, 官能基化されたボリルトリフラート型 ベンザイン前駆体候補化合物を合成した結果につい て論述する. Scheme 4 に，考案した 3 つの経路を 示す。すなわち， Grignard 試薬を用いた X-Mg 交 換反応 (route A)，パラジウム触媒を用いる宮浦ホ
ウ素化 (route B)，イリジウム触媒を用いる C-H ホウ素化 (route C) によってホウ素を導入後, ト リフラート化により 27 を合成する。 いずれの反応 も温和な条件で進行することが知られており，多様 な官能基を有するボロン酸誘導体を合成できると考 えた．以下，それぞれのルートについて検討した結 果を各項に分けて論述する. 


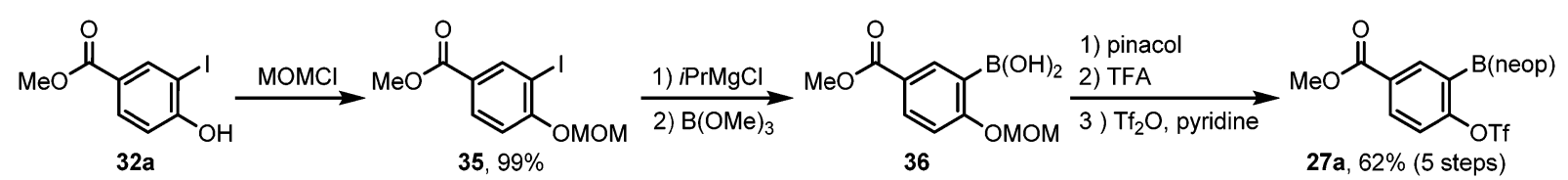

Scheme 5. Preparation of Benzyne Precursor (route A)

Table 3. Preparation of Benzyne Precursors (route B)

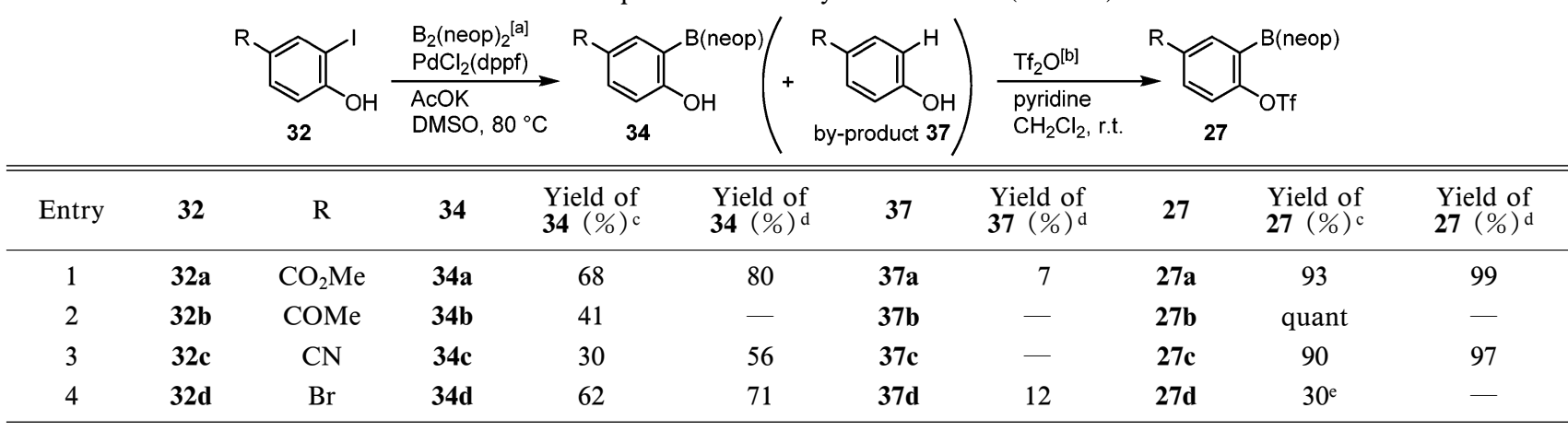

${ }^{a}$ Reaction conditions: 32 (1.0 equiv), $\mathrm{B}_{2}$ (neop) ${ }_{2}$ (1.2 equiv), $\mathrm{PdCl}_{2}$ (dppf) $\left(3.0 \mathrm{~mol} \%\right.$ ), AcOK (3.0 equiv) in DMSO $(0.13 \mathrm{M})$ at $80^{\circ} \mathrm{C}$. ${ }^{\mathrm{b}}$ Reaction conditions: 34 (1.0 equiv), $\mathrm{Tf}_{2} \mathrm{O}$ (1.5 equiv), pyridine (3.0 equiv) in $\mathrm{CH}_{2} \mathrm{Cl}_{2}(0.20 \mathrm{M})$ at r.t. ${ }^{\mathrm{c}}$ Isolated yield. ${ }^{\mathrm{d}}$ Determined by $1 \mathrm{H}$ NMR. Tetrachloroethane was used as an internal standard. ${ }^{\mathrm{e}}$ Overall isolated yield from $\mathbf{3 2}$.

4-1. Grignard 試薬を用いたボロン酸導入法 （route A） Grignard 試薬は，ボロン酸誘導体合 成に有用な求核剤として広く利用される。特に，芳 香族ヨウ素化合物から，iPrMgCl を用いてアリー ル Grignard 試薬を調製することで，多くの官能基 共存下にボロン酸誘導体を合成可能である. ${ }^{33,34)}$ そ こでまず，分子内にメトキシカルボニル基を有する ベンザイン前駆体候補化合物 27a の合成を目指した (Scheme 5)。市販のヨードフェノール誘導体 32a の $\mathrm{MOM}$ 保護により 35 を合成後, $i \mathrm{PrMgCl}$ を $-78^{\circ} \mathrm{C}$ で加え，室温まで昇温させることで Grignard 試薬 を調製し，過剩量のトリメトキシボランを加えるこ とでボリル基を導入した，得られたボロン酸誘導体 36 にネオペンチルグリコールを縮合し，MOM 基 の脱保護を行った後, 最後にトリフラート化するこ とで 27a を合成した.

以上, Grignard 試薬との共存が可能な官能基を 有する含ホウ素前駆体の合成には本法が利用可能で あることが分かった。各工程の反応は信頼性が高 $<$ ，大量合成にも適用可能な有力な前駆体合成法で あるが，水酸基の保護・脱保護を含むため，合成に 多段階を要する.

4-2. パラジウム触媒を用いる宮浦ホウ素化 （route B）宮浦ホウ素化反応は，芳香環にボリ ル基を導入する有用な反応の 1 つである. ${ }^{35,36)}$ 本反
応は，比較的低温，かつ弱塩基性条件で進行するた め，特に官能基共存性において優れている，本項で は，本手法を用いてメトキシカルボニル基，アシル 基，シアノ基，ブロモ基を有するベンザイン前駆体 候補化合物 27a-27d を合成した（Table 3）。なお， オルト位に水酸基を有する芳香族ヨウ素化合物の宮 浦ホウ素化反応では，ピナコラートボリル基 [B (pin)］の導入は困難であるが，ネオペンチルグリ コラートボリル基 [B(neop) ] を導入する場合には 極めて有力である. ${ }^{37)}$

まず，既存の方法にて合成した種々のオルトヨー ドフェノール誘導体 32 を原料とし，パラジウム触 媒及び塩基存在下， $\mathrm{B}_{2}$ (neop) ${ }_{2}$ を用いて宮浦ホウ素 化を行った，その結果，いずれの場合も反応は首尾 よく進行し，ボリルフェノール 34a-34d が得られ た。このとき，脱ヨウ素化反応が進行し副生成物 37 が生成した. 次に, 得られたボロン酸エステル 34 をトリフルオロメタンスルホン酸無水物を使つ てそれぞれトリフラート化することで，官能基を有 する前駆体候補化合物 27a-27d を合成した。本法 は，Grignard 試薬を用いる合成法と比較して，反 応工程数が少なく，共存できる官能基が多い。した がって，多様な前駆体を簡便に合成する手法として 優れているが，宮浦ホウ素化の際にプロトン化生成 物 $\mathbf{3 7}$ が副生するため, 単離精製の面で改善の余地 


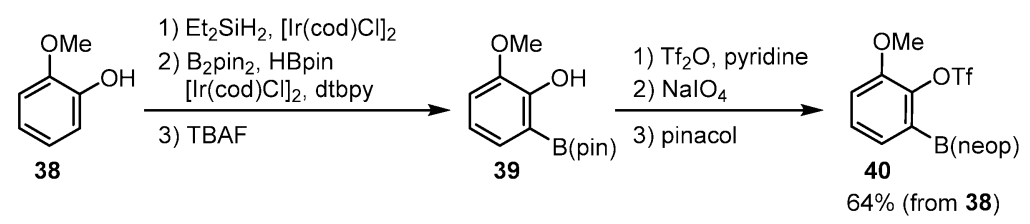

Scheme 6. Preparation of Benzyne Precursor (route C)

Table 4. $[4+2]$ Cycloaddition with Functionalized Benzynes and $\mathbf{1 1 b}^{\mathrm{a}}$

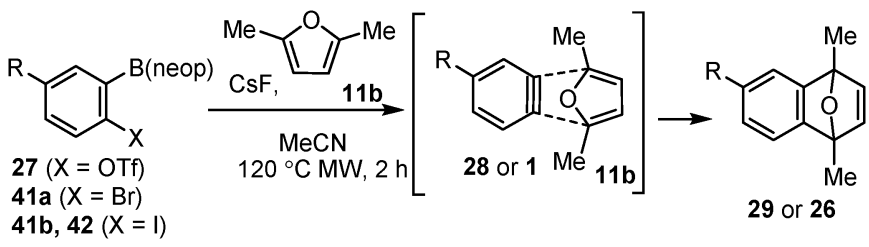

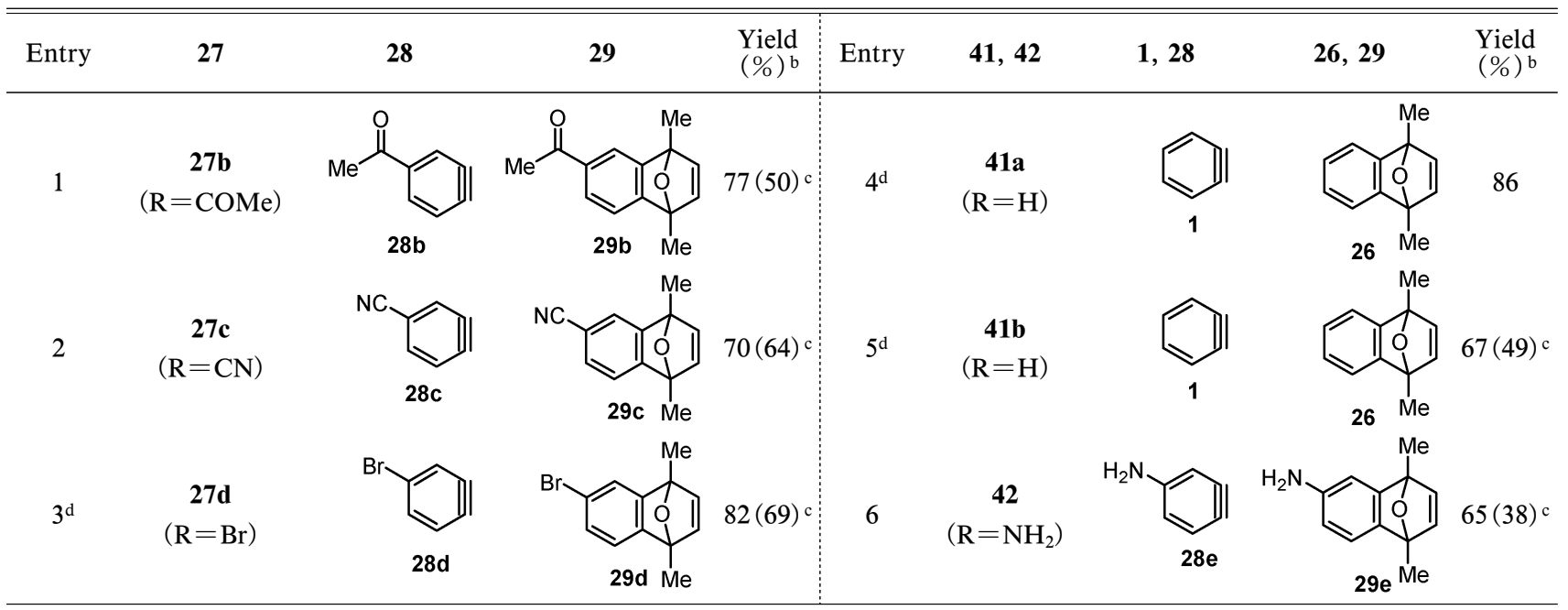

${ }^{a}$ Reaction conditions: $\mathbf{2 7}, \mathbf{4 1}, \mathbf{4 2}$ (1.0 equiv), 11b (10 equiv), CsF (2.0 equiv) in MeCN $(0.10 \mathrm{M})$ at $120^{\circ} \mathrm{C}$ using microwave for $2 \mathrm{~h} .{ }^{\mathrm{b}}$ The yield of $\mathbf{2 9}$ and $\mathbf{2 6}$ was determined via the analysis of $1 \mathrm{H}$ NMR spectra of crude products using 1,1,2,2-tetrachloroethane as an internal standard. ${ }^{\mathrm{c}}$ Isolated yield of $\mathbf{2 9}$ and $\mathbf{2 6}$ in parentheses. ${ }^{\mathrm{d}}$ Reaction was performed for $1 \mathrm{~h}$.

がある，今後は，反応条件を詳細に検討し，さらに 収率よく目的化合物が得られる手法を開発する必要 がある。

\section{4-3. イリジウム触媒を用いる C-H ホウ素化} （route C）芳香族化合物の C-H ボリル化反応 は，芳香環上に存在する $\mathrm{C}-\mathrm{H}$ 結合を活性化し，ボ リル基を導入する手法として極めて有用であ る. ${ }^{38,39)}$ Hartwig らは，シリル基を配向基とするこ とでフェノールのオルト位選択的な C-H ボリル化 反応を開発した。 ${ }^{40)}$ そこで，Hartwig らの反応を用 いてベンザイン前駆体の合成を行った．グアヤコー ル 38 を原料に用いて Scheme 6 に示すように前駆 体合成を行い，前駆体 $\mathbf{4 0}$ を合成した。 なお，ネ才 ペンチルグリコラートボリル基の直接導入は複雑な 混合物を与えたため，ピナコラートボリル基以外の ボリル基を導入する場合には多段階となる。した
がつて現段階にて本法は適用可能な基質に制限が多 いため，前駆体合成には route A 及び route B の手 法を採用することとした.

\section{5. 官能基化されたベンザインの発生と反応}

5-1. ジエン類との $[4+2]$ 付加環化反応 先 に確立した最適条件を用いて，前駆体上に置換する 官能基（R）の一般性及び，他の脱離基（X）の利 用可能性について検討した（Table 4)。すなわち， 多様な官能基 $\mathrm{R}$ 及び脱離基 X を有する前駆体 27, 41, 42 とフラン $11 b$ をフッ化セシウム存在下アセト ニトリル中, microwave 反応装置を用い $120^{\circ} \mathrm{C} て ゙$ 1-2 時間加熱し， [4+2] 付加環化生成物 29, 26 の 収率を求めた。 その結果，アセチル基，シアノ基， ブロモ基を有するベンザインの発生に成功し，付加 環化体 29b-29d を収率 50-69\%で得た（Entries 13)。また，脱離基として臭素やヨウ素を用いた場合 
Table 5. Cycloaddition of 28 with 1,3- and 1,2-Dipoles ${ }^{\text {a }}$

Entry

a Reaction conditions: 27 (1.0 equiv), 43 (10 equiv), $\mathrm{CsF}$ (2.0 equiv) in $\mathrm{MeCN}(0.10 \mathrm{M})$ at $120^{\circ} \mathrm{C}$ using microwave for $2 \mathrm{~h} .{ }^{\mathrm{b}}$ The yield of $\mathbf{4 4}$ was determined via the analysis of $1 \mathrm{H}$ NMR spectra of crude products using 1,1,2,2-tetrachloroethane as an internal standard. ${ }^{\mathrm{c}}$ distal-44a and proximal-44a $=1: 1{ }^{\mathrm{d}}$ Total isolated yield of distal $\mathbf{- 4 4}$ and proximal $\mathbf{- 4 4}{ }^{\mathrm{e}}{ }^{\mathrm{e}}$ distal $\mathbf{- 4 4 b}$ and proximal $\mathbf{- 4 4 b}=1.4: 1$. ${ }^{\mathrm{f}}$ distal-44c and proximal $-\mathbf{4 4 c}=1: 1 .{ }^{\mathrm{g}}$ distal-44d and proximal $-\mathbf{4 4 d}=1.2: 1$.

にも首尾よくベンザインは発生し，環化体 26 を与 えた（Entries 4 and 5)。 また，無保護のアミノ基 を有する前駆体 42 より，アミノ基を有するべンザ イン 28e を世界で初めて発生させることに成功し, 11b との付加環化体 29e が得られた (Entry 6). ${ }^{41)}$

5-2. 双極子化合物との $[2+2]$ 及び $(3+2)$ 付 加環化反応＼cjkstart新規含ホウ素ベンザイン前駆体から 発生させた官能基化ベンザインとフランとの $[4+2]$ 付加環化反応は良好に進行することが明らかになっ た．続いて本ベンザイン発生法の適用性を調べるた め，他の反応への適用性を検討した（Table 5)。す なわち, arynophile としてアジド 43a, ${ }^{42)}$ ケテンア セタール 43b, ${ }^{43)}$ ニトロン $43 \mathrm{c}^{44)}$ を用い，先と同様 の反応条件, microwave 反応装置を用い $120^{\circ} \mathrm{C}$ にて 1-2 時間加熱し，反応を行った。その結果，それぞ れ対応する環化付加体 44a-44d が単離収率 51-68\% で得られた（Entries 1-4）。このとき，付加環化体 の 2 種の位置異性体が $1: 1-1: 1.4$ の比で生じた.

以上の結果より，今回開発した官能基化ベンザイン 発生法は多様な反応に適用できる一般性ある手法で あることが明らかになった。

\section{6. おわりに}

本稿で筆者は，オルト位に脱離基を有するボリル
ベンゼン誘導体を用いてベンザインの効率的な発生 法を開発した。本法は Grignard 試薬やパラジウム 触媒を用いることで多様な前駆体合成が可能である こと，フッ素アニオンを用いたベンザイン発生が可 能であることから，反応性の官能基を持つベンザイ ンの発生が可能となった。 現在, より温和な条件で のベンザイン発生や市販のボロン酸誘導体からの直 接的ベンザイン発生法の開発を検討中であり，今後 のベンザイン反応を用いた新規反応の開発や生物活 性化合物の合成に貢献できるものと期待している.

\section{謝辞本研究を行うにあたり終始ご指導を賜り} ました, 大阪大学大学院薬学研究科教授 赤井周司 先生，准教授 井川貴詞先生に厚く御礼申し上げま す。また，本研究に関してご助言を賜りました神戸 薬科大学教授 奥田健介先生, 静岡県立大学大学院 薬学部教授 濱島義隆先生, 岡山大学大学院医歯薬 総合研究科教授 好光健彦先生に深く感謝致しま す。さらに本研究成果は, 実際に実験にご協力頂き ました山本梨加学士，伊藤豊浩修士を始め多くの共 同研究者との討論により得られたものであり，この 場を借りて彼らに深く感謝致します。 
利益相反 開示すべき利益相反はない.

\section{REFERENCES}

1) Wenk H. H., Winkler M., Sander W., Angew. Chem. Int. Ed., 42, 502-528 (2003).

2) Sanz R., Org. Prep. Proced. Int., 40, 215-291 (2008).

3) Yoshida H., Ohshita J., Kunai A., Bull. Chem. Soc. Jpn., 83, 199-219 (2010).

4) Tadross P. M., Stoltz B. M., Chem. Rev., 112, 3550-3577 (2012).

5) Dubrovskiy A. V., Markina N. A., Larock R. C., Org. Biomol. Chem., 11, 191-218 (2013).

6) Stiles M., Miller R. G., Burckhardt U., J. Am. Chem. Soc., 85, 1792-1797 (1963).

7) Matsumoto T., Hosoya T., Katsuki M., Suzuki K., Tetrahedron Lett., 32, 6735-6736 (1991).

8) Kitamura T., Yamane M., J. Chem. Soc. Chem. Commun., 983-984 (1995).

9) Gann A. W., Amoroso J. W., Einck V. J., Rice W. P., Chambers J. J., Schnarr N. A., Org. Lett., 16, 2003-2005 (2014).

10) Himeshima Y., Sonoda T., Kobayashi H., Chem. Lett., 12, 1211-1214 (1983) .

11) Peña D., Cobas A., Pérez D., Guitián E., Synthesis, 1454-1458 (2002).

12) Michel B., Greaney M. F., Org. Lett., 16, 2684-2687 (2014).

13) Smith A. B. III, Kim W.-S., Proc. Natl. Acad. Sci. USA, 108, 6787-6792 (2011).

14) Yoshida S., Hazama Y., Sumida Y., Yano T., Hosoya T., Molecules, 20, 10131-10140 (2015).

15) Ikawa T., Nishiyama T., Nosaki T., Takagi A., Akai S., Org. Lett., 13, 1730-1733 (2011).

16) Sapountzis I., Lin W., Fischer M., Knochel P., Angew. Chem. Int. Ed., 43, 4364-4366 (2004) .

17) Uchiyama M., Kobayashi Y., Furuyama T., Nakamura S., Kajihara Y., Miyoshi T., Sakamoto T., Kondo Y., Morokuma K., $J$. Am. Chem. Soc., 130, 472-480 (2008).

18) Yoshida S., Uchida K., Hosoya T., Chem. Lett., 44, 691-693 (2015).

19) Ikawa T., Yamamoto R., Takagi A., Ito T., Shimizu K., Goto M., Hamashima Y., Akai S., Adv. Synth. Catal., 357, 2287-2300
(2015) .

20) Matsumoto T., Hosoya T., Suzuki K., J. Am. Chem. Soc., 114, 3568-3570 (1992).

21) Ohmori K., Mori K., Ishikawa Y., Tsuruta H., Kuwahara S., Harada N., Suzuki K., Angew. Chem. Int. Ed., 43, 3167-3171 (2004).

22) Medina J. M., Mackey J. L., Garg N. K., Houk K. N., J. Am. Chem. Soc., 136, 1579815805 (2014).

23) Akai S., Ikawa T., Takayanagi S., Morikawa Y., Mohri S., Tsubakiyama M., Egi M., Wada Y., Kita Y., Angew. Chem. Int. Ed., 47, 76737676 (2008).

24) Ikawa T., Takagi A., Kurita Y., Saito K., Azechi K., Egi M., Kakiguchi K., Kita Y., Akai S., Angew. Chem. Int. Ed., 49, 55635566 (2010).

25) Takagi A., Ikawa T., Kurita Y., Saito K., Azechi K., Egi M., ItohY., Tokiwa H., Kita Y., Akai S., Tetrahedron, 69, 4338-4352 (2013).

26) Ikawa T., Tokiwa H., Akai S., Yuki Gosei Kagaku Kyokai Shi, 70, 1123-1133 (2012) .

27) Ikawa T., Takagi A., Goto M., Aoyama Y., Ishikawa Y., Itoh Y., Fujii S., Tokiwa H., Akai S., J. Org. Chem., 78, 2965-2983 (2013).

28) Ikawa T., Nishiyama T., Shigeta T., Mohri S., Morita S., Takayanagi S., Terauchi Y., Morikawa Y., Takagi A., Ishikawa Y., Fujii S., Kita Y., Akai S., Angew. Chem., Int. Ed., 50, 5674-5677 (2011).

29) Takagi A., Ikawa T., Saito K., Masuda S., Ito T., Akai S., Org. Biomol. Chem., 11, 81458150 (2013).

30) Ikawa T., Masuda S., Nishiyama T., Takagi A., Akai S., Aust. J. Chem., 67, 475-480 (2014).

31) Sumida Y., Kato T., Hosoya T., Org. Lett., 15, 2806-2809 (2013).

32) García-López J.-A., Greaney M. F., Org. Lett., 16, 2338-2341 (2014).

33) Wang X.-J., Sun X., Zhang L., Xu Y., Krishnamurthy D., Senanayake C. H., Org. Lett., 8, 305-307 (2006).

34) Leermann T., Leroux F. R., Colobert F., Org. Lett., 13, 4479-4481 (2011).

35) Ishiyama T., Murata M., Miyaura N., J. Org. Chem., 60, 7508-7510 (1995). 
36) Murata M., Oyama T., Watanabe S., Masuda Y., J. Org. Chem., 65, 164-168 (2000).

37) Fang H., Kaur G., Yan J., Wang B., Tetrahedron Lett., 46, 1671-1674 (2005).

38) Ishiyama T., Takagi J., Ishida K., Miyaura N., Anastasi N. R., Hartwig J. F., J. Am. Chem. Soc., 124, 390-391 (2002).

39) Mkhalid I. A., Barnard J. H., Marder T. B., Murphy J. M., Hartwig J. F., Chem. Rev., 110, 890-931 (2010).
40) Boebel T. A., Hartwig J. F., J. Am. Chem. Soc., 130, 7534-7535 (2008).

41) Maurin P., Ibrahim-Ouali M., Parrain J.-L., Santelli M., Theochem, 637, 91-100 (2003).

42) Shi F., Waldo J. P., Chen Y., Larock R. C., Org. Lett., 10, 2409-2412 (2008).

43) Stevens R. V., Bisacchi G. S., J. Org. Chem., 47, 2393-2396 (1982).

44) Lu C., Dubrovskiy A. V., Larock R. C., J. Org. Chem., 77, 2279-2284 (2012). 